\title{
Environmental, social and governance disclosure associated with the firm value. Evidence from energy industry
}

\author{
Daniela Constantinescu ${ }^{1, a}$, Chirața Caraiani ${ }^{\mathrm{a}}$, Camelia I. Lungu ${ }^{\mathrm{a}}$ \\ and Pompei Mititean ${ }^{\mathrm{a}}$
}

${ }^{\mathrm{a}}$ Bucharest University of Economic Studies, Romania

\begin{abstract}
Research Question: Is there an association between ESG factors disclosure and the firm's value for the companies acting in energy sector?

Motivation: Identifying whether a connection exists between the ESG factors disclosure and firm's value is a current and much debated matter, with a focus on the presentation of non-financial information. The necessity of demonstrating the existence of an association is based on the inclusion of non-financial information in the company's corporate reporting combined with financial information. Non-financial information presents the long-term prospects of a company and is focused on the value creation process, as opposed to financial information which is limited to historical data and short-term goals such as profit maximisation. In order to describe the value creation process, the company is analysed from different stakeholders' points of view (customers, suppliers, employees, local community, government, environments activists, etc.) and the interdependencies created between the company and these stakeholders. Therefore, by choosing to present a more holistic view of a company, the management of the company may attract new capital from investors by showing that there is a positive association between ESG factors and firms' value (Sadiq et al., 2020; Wong et al., 2020).
\end{abstract}

Idea: This paper assesses the possibility of an association between ESG factors and firm's value by developing two linear regression models.

Data: The data used for the research was collected from Thomson Reuters platform based on Top 100 Global Energy Leaders established by the analysists from Thomson Reuters.

Tools: The SPSS statistic program was used to apply the two research models on the data collected.

1 Corresponding author: Daniela Constantinescu; Bucharest University of Economic Studies; university address; constantinescudaniela11@ @stud.ase.ro tel. (+40) 720659279 
Findings: The main findings of the research is that there is an association between ESG factors disclosure and firm's value, and based on the type of the connection (positive or negative), companies may include aspects regarding non-financial information, namely ESG factors, which could attract new capital.

Contribution: This paper contributes to the previous research conducted on the disclosure of ESG factors and its influence on firm's value by showing that there is an association between ESG factors disclosure and the value of the company. The evidence obtained based on the two research models applied to the dataset may persuade the management of the companies to include non-financial information in their corporate reporting.

Keywords: Environmental, social, and corporate governance (ESG), firm's value, corporate performance, Energy industry.

\section{JEL codes: M14}

\section{Introduction}

The past decades have showed that there is an increasing interest in the presentation and inclusion of non-financial information in the company's corporate reporting. The enhanced attention given to the presentation of non-financial information is a result of the last financial crisis (2007-2008) and the accelerated development of technology. Investors are no longer interested only in the financial aspects related to a company, they are looking at the company's possibilities for value creation and sustainable development. ESG factors are representative aspects of non-financial information towards which companies, markets and investors have focused (Setyahuni \& Handayani, 2020).

The disclosure of ESG factors provides a new and complex insight into a company's activity as compared with the one offered by the financial information. The presentation of financial information discloses historical data and it is focused on short-term goals, such as the maximisation of shareholders' wealth seen as the major stakeholder of the company which is achieved through the interaction between shareholders and the management of the company (Anning, 2018; Li et $a l ., 2018$ ). The increased pressure of the stock markets and investors encourages companies to provide additional non-financial information focusing on ESG factors disclosure.

Underlying on the increasing focus on the long-term goals of the business detrimental to short-term goals, the paper explores the possible association between ESG factors and firm's value. The long-term goals move the focus of the company from the profit maximisation to the performance measured through EGS factors. This research considers individual dimensions of ESG factors (environment, social, and corporate governance), along with the combined score. The environment factor 
describes the relation between the organisation, its activity and environment represented by natural resources (water, air, soil, vegetation, and fauna etc.). The impact produced by the business activities on the environment and the manner in which the company is managing to limit its negative effects on environment are considered. The social factor refers to the connection between the organization and its employees, customers, suppliers, and the communities in which the company is conducting its business activity. The corporate governance factor relates to the company's leadership system, the implemented controls systems, the relationship with the shareholders, and the connection between shareholders and executives. The investors and other stakeholders (clients, suppliers, banks, local communities, governments, employees, and others) consider ESG factors to improve the firm's financial performance (Zhao et al., 2018).

The aim of this research is to investigate possible associations between environmental, social and governance (ESG) factors' disclosure and the value of companies from energy industry. It contributes to a better understanding of the specific characteristics of energy industry in terms of ESG-related policies. Arguments for choosing energy industry start with the pioneering sustainabilityoriented activities (Hughey \& Sulkowski, 2012) and relay on the increasing importance conferred by researchers and scientific journals' editors, overtime (Soytas et al., 2017; Patari et al., 2014; Lu et al., 2014), as highlighted by Lungu et al. (2019).

Considering the last decades, numerous studies investigating the relationship between the ESG factors and the firm's value have been published. Regardless of the great number of papers on this matter, the results are conflicting. Evidence is provided for the existence of a positive association of the ESG factors on the firm's value (Sadiq et al., 2020; Wong et al., 2020; Yoon et al., 2018; Yu et al., 2018; Friede et al., 2015), while others report a negative association (Friede et al., 2015; Horváthová, 2010; Brammer et al., 2006; Richardson \& Welker, 2001) or even no influence at all (Friede et al., 2015) when various measures are used for ESG factors and firm's value.

The present paper is based on one main hypothesis in determining whether there is an association between ESG factors disclosure and the firm's value for the companies activating in energy sector.

H1: There is an association between ESG factors disclosure and the firm's value for the companies activating in energy sector.

Several secondary assumptions result from the main hypothesis, such as:

H1.1: There is an association between environment disclosure and the firm's value for the companies activating in energy sector.

H1.2: There is an association between social disclosure and the firm's value for the companies activating in energy sector. 
H1.3: There is an association between corporate governance disclosure and the firm's value for the companies activating in energy sector.

In order to develop a research design to address the hypotheses, ESG scores available on Thomson Reuters Eikon platform were used to measure the disclosure of ESG factors, as for the firm's value, market value and Tobin's Q were considered. The initial sampling size consisted of the top 100 companies from energy industry classified by Thomson Reuters, whilst the final sample was diminished to 67 companies with data over a period of four years (2015-2018), because of unavailability of data.

The results obtained are similar with other studies that investigated the relationship between ESG factors disclosure and firm's value (Sadiq et al., 2020; Wong et al., 2020; Li et al., 2018; Fatemi et al., 2018; Horváthová, 2010) and they are providing additional evidence supporting the existence of a relationship for companies within Energy sector.

The remainder of this paper advances as follows: the second section reviews the prior research, while the third section presents the research design, referring to sample and data, variables, and research method. The fourth section is dedicated to the research results. Conclusions are provided in the fifth section.

\section{Literature review}

The literature has integrated countless studies regarding the relationship between ESG factors and the company's value in the last decades. Some of these studies present a positive impact of the ESG factors on the firm's value (Sadiq et al. 2020; Wong et al., 2020; Yoon et al., 2018; Yu et al., 2018; Friede et al., 2015), while others report a negative association (Friede et al., 2015; Horváthová, 2010; Brammer et al., 2006; Richardson \& Welker, 2001) or even no influence at all (Friede et al., 2015). Considering the increased implication of accounting associations, such as ACCA, militating for the inclusion of integrated reporting as part of the corporate reporting, environment organisations, climate and human rights activists, but also the interest manifested for ESG factors by stock markets and investors, further studies on the relationship between ESG factors and company's value are expected to be generated, but not limited to this relation only.

Wong et al. (2020) conducted a research on the impact between ESG certification and firm's value for Malaysian listed companies over the period 2005 to 2018. Their results showed positive impact of ESG certification on firm's value (measured by Tobin's Q) and benefits to shareholders. Thus, the authors encourage organisations to report aspects related with ESG factors and to focus on long-term goals for the companies, instead of short-term goals which bring little value to the company. The adoption on long-term objective may help the company to create 
value for all its stakeholders by combining non-financial information presenting aspects about ESG factors with financial information.

Another study concentrated on the impact of ESG factors disclosure on firm value for Malaysian companies is the one prepared by Sadiq et al. (2020). The authors have applied the regression model on a dataset of 122 listed companies on Malaysia Stock Exchange for a period of 9 years (2011-2019). Their results are consistent with the ones obtained by Fatemi et al. (2018), and state that ESG strengths increase firm's value while ESG weaknesses decrease it. Sadiq et al. (2020) and Fatemi et al. (2018) asserted that the disclosure of ESG factors has a moderating role in diminishing the negative effects of weaknesses and reducing the positive effect of strengths.

A recent research on the association between ESG factors and performance of the company is the one conducted by Alareeni and Hamdan (2020). The study is focused on a dataset of US S\&P 500 listed companies during a 10-year period (from 2009 to 2018) on which the authors have used a panel regression analysis. Their outputs show a positive impact of ESG factor's disclosure on firm's performance represented by Tobin's Q. The study analysis the outputs for each individual factor demonstrating that there is a positive association between individual environment, corporate governance factors and Tobin's Q. A notable observation of the paper is that combined and individual ESG factors have higher scores for stable and financially sane companies.

The current serious climate matters and the increased power of the employees have shifted the attention of the company's management and investors from financial aspects to aspects focusing on preserving the environment and enhancing the support delivered by companies to their employees. De Lucia et al., (2020) have conducted an investigation on whether good ESG scores lead to a better financial performance for public companies from Europe. The results of the regression models applied show that there is a positive relation between ESG practice and financial performance, connection that is enhanced by the investment in environment and social aspects. Therefore, as a positive relation is demonstrated between ESG factors and financial performance, it may be possible for the financial performance to influence in a positive manner the value of the company.

Li et al. (2018) has also investigated whether the disclosure of ESG factors may have an influence on the firm's value. They used a database of 350 FTSE listed companies and concluded based on two regression models used that there is a positive association between ESG disclosure and firm's value. Furthermore, the authors demonstrate that the firms with a CEO delegated with a higher level of power present an enhanced influence of ESG disclosure on company's value.

The sustainability evaluated through ESG factors was found to have a positive and significant impact on market value for companies activating in an emerging market 
(Yoon et al., 2018). The study is based on a sample of 705 companies in South Korea, of which 190 firms from environmentally sensitive industries such as energy (equipment and services, oil and gas, consumable fuel industries), material (chemicals, construction materials, containers and packaging, metals and mining industries) and utility sector (producers of electricity, gas, water, renewable energy). Results show that the impact is influenced by the attributes of the firm. Thus, for environmentally sensitive industries the impact of ESG factors on firm's value is less significant as compared to the non-sensitive industries. Yoon et al. (2018) have also stated that the corporate governance has a negative impact on firm's value for those companies belonging to sensitive industries.

Positive association between ESG factors disclosure and firm's value was also found in Yu et al. (2018) research, for 1996 companies from 47 developed and emerging countries. Authors militate for the implementation of ESG disclosure in case of average listed companies in order to enhance the firm's value measured by Tobin's Q. The costs related to the implementation may be recovered in time, and the companies financially sound will achieve a better transparency in ESG disclosure.

Friede et al. (2015) reviewed more than 2200 individual studies concentrated on the relation between environmental, social and governance (ESG) and corporate financial performance, being one of the first investigations to gather aggregated evidence from a significant number of earlier studies. By applying vote-counting and meta-analysis techniques, their results showed that almost $90 \%$ of the studies demonstrates a non-negative relation between ESG and corporate financial performance along with the fact that the mainstream of the studies considered show positive findings related to studied association. The authors obtained supporting evidence that investing in ESG and long-term goals will bring added value to the company and additionally the positive impact of ESG on financial performance seems to be steady over time.

The interdependency between environmental performance and financial performance was explored by Liu (2020) for different industries by performing a multilevel longitudinal analysis. The results present an overall positive relationship between environment performance and financial performance. Regardless of the positive connection identified, a negative association between environment performance and financial performance is demonstrated for sensitive industries and is based on a general lack of trust between major stakeholders from these sensitive sectors.

Richardson and Welker (2001) have studied the relationship between ESG disclosure and market value for a sample of Canadian companies in the yearly 90's. The results suggest a negative association between ESG disclosure and market. The same type of relation between social performance and stock returns was identified 
by Brammer et al. (2006) for UK companies. Moreover, the investigation of Horváthová (2010) shows a possible negative association between environmental and financial performance, enhanced by using correlation coefficients and portfolio studies, as opposed of using multiple regressions and panel data technique. Horváthová (2010) suggested that the time framework plays a major role in determining the relationship between environment and financial performance, as it takes some time for the environmental regulations to have an influence in financial performance.

\section{Research design}

\subsection{Sample and data}

To investigate the association between the ESG factors disclosure and firm's value for companies within energy industry, the latest top (2017) established by the analysts from Thomson Reuters (Top 100 Global Energy Leaders https://www.thomsonreuters.com/en/products-services/energy/top-100.html) was used. The analysts from Thomson Reuters have created the Top 100 Global Energy Leaders based on eight criteria (https://www.thomsonreuters.com/en/productsservices/energy/top-100/methodology.html): management \& investor confidence; legal compliance; financial performance; innovation; risk and resilience; people and social responsibility; reputation; and environmental impact.

Out of 100 companies from the Thomson Reuters classification, for 33 companies, no information at all (financial information or ESG related - 5 companies), no ESG scores data (27 companies), or only partial ESG scores (1 company) were found at the time of data collection. For the remaining 67 companies, with the required data available on Thomson Reuters site or in their annual reports, a total sample of 266 company-year observations, grouped on 4 years $(2015-2018)$, was tested. The companies were also classified in 4 sub-categories of the Energy industry (Oil and Gas, Oil \& Gas Related Equipment and Services, Multiline Utilities, Renewable Energy and Uranium), for six geographical regions (Table 1).

Table 1. Description of the database

\begin{tabular}{|c|c|c|c|c|c|c|c|}
\hline Geographical region & 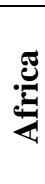 & $\frac{\frac{\pi}{2}}{2}$ & 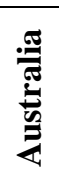 & 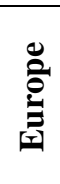 & 吾 & 吾 & $\stackrel{\bar{\sigma}}{\theta}$ \\
\hline \multicolumn{8}{|l|}{$\begin{array}{l}\text { Panel A. Number of companies included in } \\
\text { the analysis }\end{array}$} \\
\hline Multiline Utilities & & & & 6 & 4 & & 10 \\
\hline Oil \& Gas & 1 & 17 & 2 & 17 & 4 & 2 & 43 \\
\hline Oil \& Gas Related Equipment and Services & & & & 6 & 3 & & 9 \\
\hline
\end{tabular}


Environmental, social and governance disclosure associated with the firm value. Evidence from energy industry

\begin{tabular}{|c|c|c|c|c|c|c|c|}
\hline $7^{\text {Geographical region }}$ & 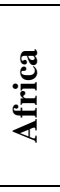 & $\frac{\frac{\pi}{2}}{4}$ & 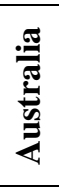 & 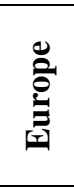 & 焉 & 鹃 & 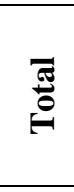 \\
\hline Renewable Energy & & & & 2 & 2 & & 4 \\
\hline Uranium & & & & & 1 & & 1 \\
\hline Total countries & 1 & 17 & 2 & 31 & 14 & 2 & 67 \\
\hline $\begin{array}{l}\text { Panel B. Number of company-year } \\
\text { observations included in the analysis }\end{array}$ & & & & & & & \\
\hline Multiline Utilities & & & & 24 & 15 & & 39 \\
\hline Oil \& Gas & 4 & 68 & 8 & 68 & 16 & 8 & 172 \\
\hline Oil \& Gas Related Equipment and Services & & & & 23 & 12 & & 35 \\
\hline Renewable Energy & & & & 8 & 8 & & 16 \\
\hline Uranium & & & & & 4 & & 4 \\
\hline Total country-year observations & 4 & 68 & 8 & 123 & 55 & 8 & 266 \\
\hline
\end{tabular}

Thomson Reuters Eikon platform was used to collect the scores for the combined and individual ESG factors presented as numerical values for the period 2015 2018. The 4-year period was selected since most companies selected have the scores available for this period. The financial information measuring the firm's value for the companies in the sample was also obtained from the Thomson Reuters Eikon platform, and, where the information was not available on the platform (total assets and cash and cash equivalents), it was collected from the company's published annual reports. All the figures taken into consideration are presented in US dollars as it represents a main global currency.

\subsection{Variables}

Details related to the variables used in this research are summarised in Table 2. To have a holistic approach on the dependent variable measuring the firm's value, two financial indicators were considered: the market value (also used by Fatemi et al., 2018 and Brammer et al., 2006) included in the regression model as natural logarithm (LNMV) and TOBIN's Q (considered also in Li et al., 2018; Fatemi et al., 2018; and Yu et al., 2018 studies) computed as market value scaled by total assets.

The ESG score available on Thomson Reuters Eikon platform is considered to be the independent value agreed for the linear regression models. The scores vary from 0 to $100 \%$ and are computed based on data concerning corporate governance, economic, environmental, and social aspects. Thomson Reuters ESG scores were utilized because the information on the basis of which they are computed comes directly from the companies, hence, there is a high degree of reliability and 
originality for these scores. ESG scores are variable used in numerous studies which investigates the connection between the ESG factors disclosure and firm's value (Li et al., 2018; Fatemi et al., 2018; Yoon et al., 2018), regardless of the source from which they have been extracted (Bloomberg; Kinder, Lydenberg and Domini; Thomson Reuters). For the detailed scenarios analysed in the paper, the environment, social and corporate governance pillars were also considered.

Table 2. Variables used in the linear regression model

\begin{tabular}{|c|c|c|c|}
\hline Variable & $\begin{array}{c}\text { Type } \\
\text { of variable }\end{array}$ & Description & $\begin{array}{c}\text { Referenced } \\
\text { studies/research }\end{array}$ \\
\hline LNMV & dependent & $\begin{array}{l}\text { Natural logarithm of market } \\
\text { value available on Thomson } \\
\text { Reuters platform }\end{array}$ & $\begin{array}{l}\text { Fatemi et al. (2018); Li et } \\
\text { al. }(2018) \text {; Brammer et al. } \\
(2006)\end{array}$ \\
\hline Tobin's Q & dependent & $\begin{array}{l}\text { Computed as the report } \\
\text { between market value and } \\
\text { total assets }\end{array}$ & $\begin{array}{l}\text { Alareeni \& Hamdan } \\
\text { (2020); Li et al. (2018); } \\
\text { Fatemi et al. (2018); Yu et } \\
\text { al. (2018) }\end{array}$ \\
\hline ESG & independent & ESG scores available on & Li et al. (2018); Fatemi et \\
\hline & & Thomson Reuters & $\begin{array}{l}\text { al. (2018); Yoon et al. } \\
\text { (2018) }\end{array}$ \\
\hline ENV & independent & $\begin{array}{l}\text { Environment score available } \\
\text { on Thomson Reuters }\end{array}$ & $\begin{array}{l}\text { Fatemi et al. (2018); Yoon } \\
\text { et al. (2018) }\end{array}$ \\
\hline SOC & independent & $\begin{array}{l}\text { Social score available on } \\
\text { Thomson Reuters }\end{array}$ & $\begin{array}{l}\text { Fatemi et al. (2018); Yoon } \\
\text { et al. (2018) }\end{array}$ \\
\hline GOV & independent & $\begin{array}{l}\text { Corporate Governance score } \\
\text { available on Thomson Reuters }\end{array}$ & $\begin{array}{l}\text { Fatemi et al. (2018); Yoon } \\
\text { et al. (2018) }\end{array}$ \\
\hline CASH_TA & control & $\begin{array}{l}\text { Computed as the report } \\
\text { between cash and cash } \\
\text { equivalents value and total } \\
\text { assets, both publish on } \\
\text { Thomson Reuters }\end{array}$ & Li et al. (2018) \\
\hline LNTR & control & $\begin{array}{l}\text { Natural logarithm of total } \\
\text { revenues related with the } \\
\text { business activities of the } \\
\text { company, available on } \\
\text { Thomson Reuters }\end{array}$ & Fatemi et al. (2018) \\
\hline
\end{tabular}

Apart from ESG combined and individual scores, which is set as the independent variable in the linear regression models, data for the following control variables identified by the literature to be noteworthy in identifying the relationship between the ESG factors disclosure and firm's value: total revenues from business activity (Fatemi et al., 2018), for which it was applied a natural logarithm function for comparability purposes (LNTR), and CASH_TA ratio (Li et al., 2018) computed as the value of cash and cash equivalents scaled by total assets (CASH_TA). 
To open the discussion for the research's sub-hypothesis, Figure 1 shows the differences at the region level, for companies from Energy sector regarding the dependent and independent variables considered for this study. Asia and Europe are leading the top, being the regions with the greatest average of ESG combined and individual scores. However, North America and South America are following shortly behind. Australia and Africa are the regions occupying the last two positions. This may come as a surprise for Africa as it is mandatory for companies listed on Johannesburg Stock Exchange to prepare an integrated report through which aspects related to environment, social and corporate governance factors are presented. As for the Tobin's Q indicator, the highest value per region was recorded in South America and the lowest in Europe. Natural logarithm of market value is approximatively the same in all the above regions, the highest value been recorded in Asia and the lower in Europe.

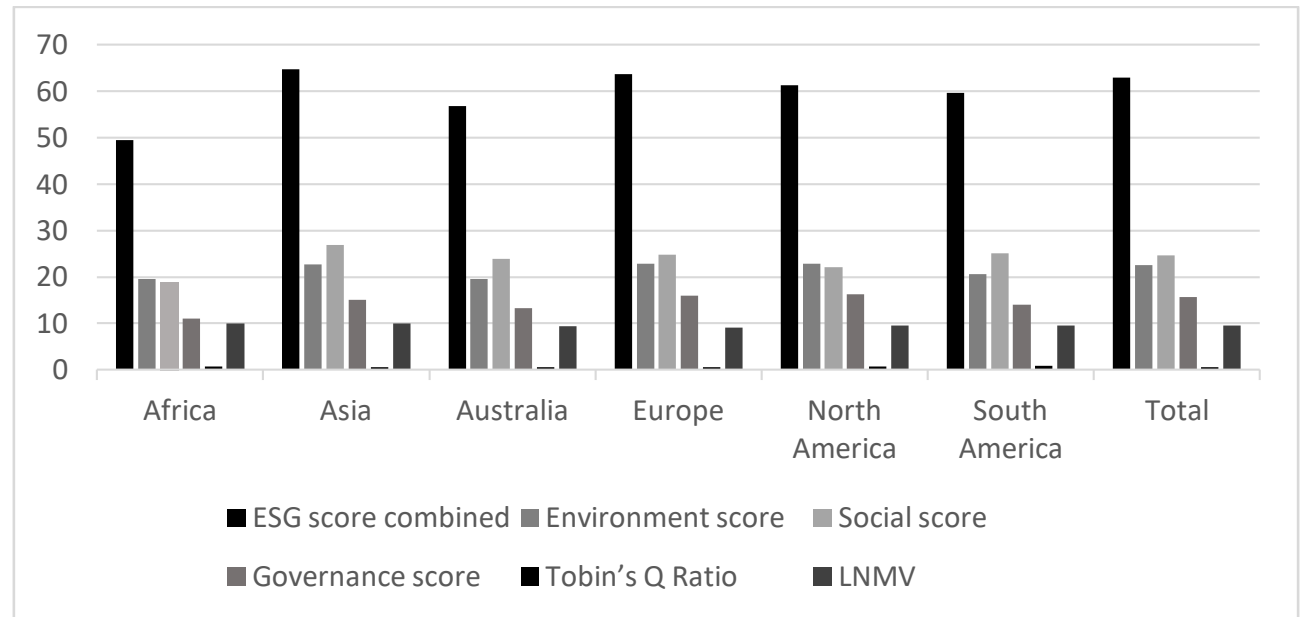

Figure 1. ESG scores combined and individual, Tobin's $Q$ and market value by geographical region

The average values showed by the comparative graphic analysis highlighted the need for an in-depth testing, with details for the possible associations generated for each geographical region and a related interpretation.

\subsection{Research method}

The linear regression analysis was used to estimate the type of relationship between the dependent variable (firm's value) and the independent variable (ESG factors). Regression analysis was widely used in other research studies on a fixed dataset (Fatemi et al., 2018; Li et al., 2018) to infer on the casual relationship between the ESG factors disclosure and firm's value. The SPSS statistical program was used to run the regression models to the selected sample. The regression models were applied to the ESG combined score and to the score of each individual factor 
(environment, social and corporate governance) to better observe the impact of ESG factors disclosure to firm's value.

The primary research hypothesis on the association between ESG factors disclosure and the firm's value for international companies within Energy sector is tested within two main scenarios. Thus, two linear regression models were created, one using natural logarithm of market value to represent the dependent variable, and the other one using Tobin's $Q$ for the dependent variable:

Scenario $1 \quad \mathrm{LNMV}_{\mathrm{t}}=\beta_{0}+\beta_{1} \mathrm{ESG}+\beta_{2} \mathrm{CASH}_{-} \mathrm{TA} \mathrm{t}_{\mathrm{t}}+\beta_{3} \mathrm{LNTR}_{\mathrm{t}}+\varepsilon_{\mathrm{t}}$

Scenario 2 Tobin's $\mathrm{Q}_{\mathrm{t}}=\beta_{0}+\beta_{1} \mathrm{ESG}_{\mathrm{t}}+\beta_{2} \mathrm{CASH}_{-} \mathrm{TA}_{\mathrm{t}}+\beta_{3} \mathrm{LNTR}_{\mathrm{t}}+\varepsilon_{\mathrm{t}}$

Furthermore, each main scenario is disaggregated in three secondary scenarios which assesses the model for the three pillars of ESG factors: environment, social, and governance:

$$
\begin{aligned}
& \text { Scenario 1.1 } \text { LNMV }_{\mathrm{t}}=\beta_{0}+\beta_{1} \mathrm{ENV}_{\mathrm{t}}+\beta_{2} \mathrm{CASH}_{-} \mathrm{TA}_{\mathrm{t}}+\beta_{3} \mathrm{LNTR}_{\mathrm{t}}+\varepsilon_{\mathrm{t}} \\
& \text { Scenario 1.2 } \text { LNMV }_{\mathrm{t}}=\beta_{0}+\beta_{1} \mathrm{SOC}_{\mathrm{t}}+\beta_{2} \mathrm{CASH}_{-} \mathrm{TA}_{\mathrm{t}}+\beta_{3} \mathrm{LNTR}_{\mathrm{t}}+\varepsilon_{\mathrm{t}} \\
& \text { Scenario 1.3 } \mathrm{LNMV}_{\mathrm{t}}=\beta_{0}+\beta_{1} \mathrm{GOV}_{\mathrm{t}}+\beta_{2} \mathrm{CASH}_{-} \mathrm{TA}_{\mathrm{t}}+\beta_{3} \mathrm{LNTR}_{\mathrm{t}}+\varepsilon_{\mathrm{t}} \\
& \text { Scenario 2.1 Tobin's } \mathrm{Q}_{\mathrm{t}}=\beta_{0}+\beta_{1} \mathrm{ENV}_{\mathrm{t}}+\beta_{2} \mathrm{CASH}_{-} \mathrm{TA}_{\mathrm{t}}+\beta_{3} \mathrm{LNTR}_{\mathrm{t}}+\varepsilon_{\mathrm{t}} \\
& \text { Scenario } 2.2 \text { Tobin's } \mathrm{Q}_{\mathrm{t}}=\beta_{0}+\beta_{1} \mathrm{SOC}_{\mathrm{t}}+\beta_{2} \mathrm{CASH}_{-} \mathrm{TA}_{\mathrm{t}}+\beta_{3} \mathrm{LNTR}_{\mathrm{t}}+\varepsilon_{\mathrm{t}} \\
& \text { Scenario } 2.3 \text { Tobin's } \mathrm{Q}_{\mathrm{t}}=\beta_{0}+\beta_{1} \mathrm{GOV}_{\mathrm{t}}+\beta_{2} \mathrm{CASH}_{-} \mathrm{TA}_{\mathrm{t}}+\beta_{3} \mathrm{LNTR}_{\mathrm{t}}+\varepsilon_{\mathrm{t}}
\end{aligned}
$$

The regression models have been created based on key dependent and independent variables identified in the specialized literature to reveal the type of association between ESG factors disclosure and firm's value. The subscript allocated to each variable within the model represents the company-year observation. The independent variable of the research model is exemplified by the combined, or individual ESG factors scores, a frequent choice in the prior literature. The numerical values for the scores were downloaded for Thomson Reuters platform, where the information was available. As for the dependent variable, representing the firm's value, two variables were used for a holistic understanding: market value and Tobin's Q, the data was also obtained from the Thomson Reuters platform, or when not available, company's annual reports. Additionally, the following controls variables, identified to be pertinent from previous studies were included: cash and cash equivalents scaled by total assets, and total revenues from business activities.

\section{Research results}

\subsection{Descriptive statistics and correlation analysis}

Prior to analyse the coefficients of the two regression models which are based on estimates of scenarios resulting from different combinations of independent and 
dependent variables, the data used for the research has been assessed. Descriptive statistics are computed for the regression variables in SPSS software (Table 3) and addressed the assumption that the data is normally distributed, and the regression models based on these variables are valid. As a result of a high skewness, the variables, market value and total revenues, were transformed using natural logarithms.

Assessing the Pearson correlation coefficient (Table 4, above the diagonal), it can be observed that corporate governance score $(\mathrm{GOV})$ is positively correlated with Tobin's Q ratio, at a significance level of 0.05 , but at the same time, the corporate governance score is negatively correlated with natural logarithm of market value, at a significance level of .05 , providing evidence in the support of the research hypothesis H1.3. According to Pearson correlation, different and conflicting results are obtained for each of the two research models used. In addition to Pearson results, the correlation obtained for corporate governance score in relation with natural logarithm of market value is also validated by the Spearman correlation (Table 4, below the diagonal), with a negative coefficient of 0.127 ( $\mathrm{p}<0.05)$, which shows a higher significant association between governance score and market value. 

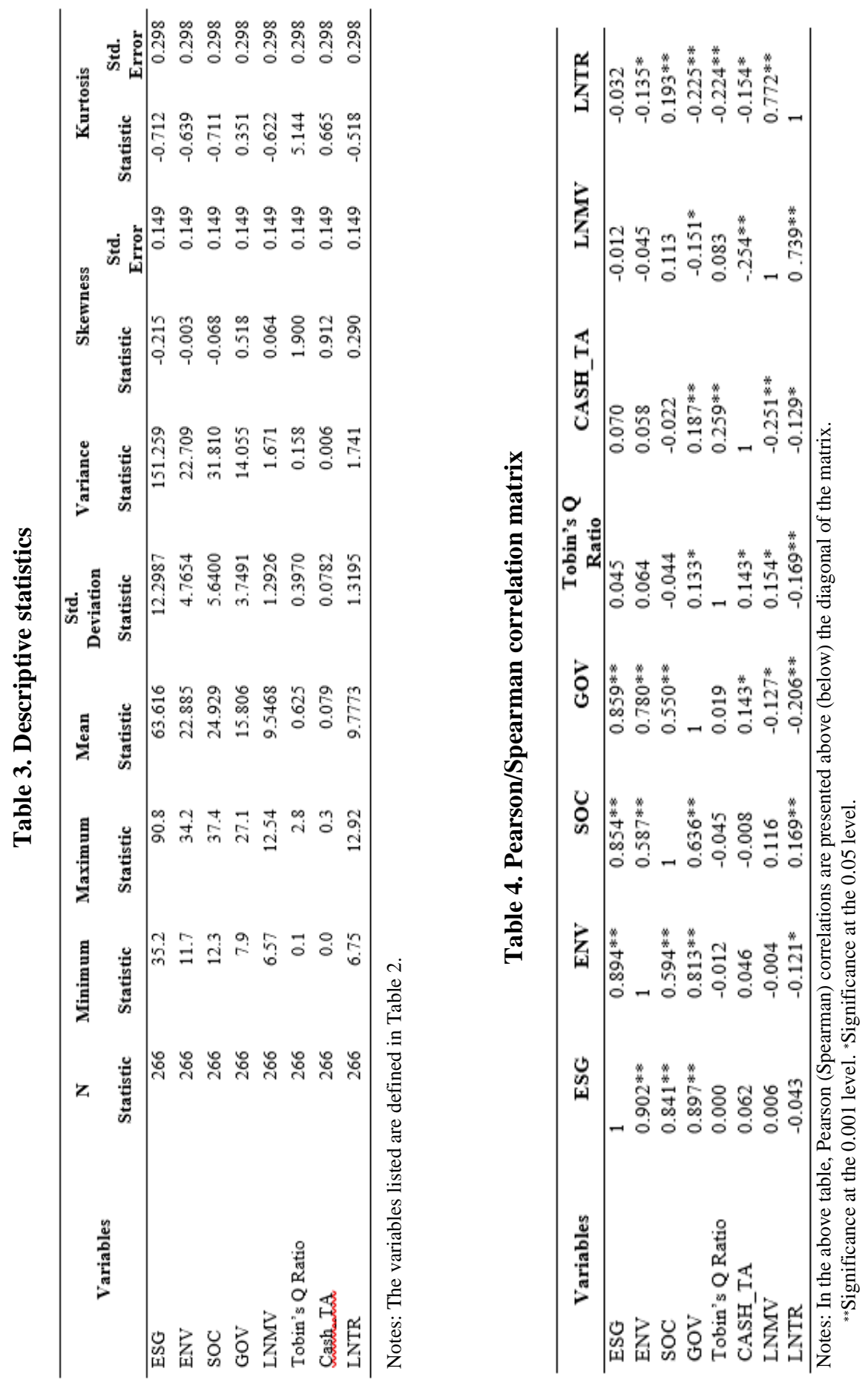


\subsection{Discussion on the research hypotheses}

When assessing the association between ESG factors disclosure and firm's value, the correlation has been analysed for the full sample considered, and for each of the five regions (Africa, Asia, Australia, Europe, North America, and South America). The significant econometric models in terms of sample size and $\mathrm{F}$ statistics were identified for the three regions presented in Table 5 and Table 6 . Thus, the regions selected are North America, Europe, and Asia, based on the outputs resulted from SPSS software.

The relationship between ESG combined scores and firm's value represented by market value, overall and per each of the three regions, is analysed in the first main scenario (Scenario 1), presented in Table 5. The regression model is the following: $L N M V_{t}=\beta_{0}+\beta_{1} E S G_{t}+\beta_{2} C A S H_{-} T A_{t}+\beta_{3} L N T R_{t}+\varepsilon_{t}$. Three sub-scenarios are disaggregated from Scenario 1 to assess the association between each of the ESG factors (environment, social and corporate governance) and firm's value, represented in this scenario by natural logarithm of market value.

Table 5. The impact of market value on ESG factors' disclosure

\begin{tabular}{|c|c|c|c|c|c|c|c|c|}
\hline \multirow{2}{*}{$\begin{array}{c}\text { Dependent } \\
\text { Variable: LNMV } \\
\text { Scenario } 1\end{array}$} & \multicolumn{2}{|c|}{ Overall sample } & \multicolumn{2}{|c|}{ North America } & \multicolumn{2}{|c|}{ Europe } & \multicolumn{2}{|c|}{ Asia } \\
\hline & Coefficient & Sig. & Coefficient & Sig. & Coefficient & Sig. & Coefficient & Sig. \\
\hline (constant) & 2.384 & 0.466 & 0.891 & 0.665 & -0.149 & 0.774 & 2.416 & 1.065 \\
\hline ESG & 0.002 & 0.004 & 0.014 & 0.006 & 0.009 & 0.005 & -0.009 & 0.009 \\
\hline CASH TA & -2.315 & 0.642 & -2.635 & 0.968 & -1.765 & 0.856 & 3.598 & 1.445 \\
\hline LNTR & 0.736 & 0.038 & 0.881 & 0.064 & 0.923 & 0.061 & 0.756 & 0.076 \\
\hline F statistic & 139.963 & & 78.755 & & 91.098 & & 33.617 & \\
\hline Durbin-Watson & 2.023 & & 1.937 & & 1.619 & & 1.168 & \\
\hline Adjusted R-square & 0.611 & & 0.812 & & 0.689 & & 0.594 & \\
\hline Scenario 1.1 & Coefficient & Sig. & Coefficient & Sig. & Coefficient & Sig. & Coefficient & Sig. \\
\hline (constant) & 2.050 & 0.478 & 0.697 & 0.810 & -0.240 & 0.720 & 1.843 & 1.105 \\
\hline ENV & 0.018 & 0.010 & 0.026 & 0.017 & 0.029 & 0.013 & -0.001 & 0.028 \\
\hline CASH_TA & -2.332 & 0.638 & -2.468 & 0.996 & -1.714 & 0.849 & 3.295 & 1.523 \\
\hline LNTR & 0.744 & 0.038 & 0.928 & 0.066 & 0.922 & 0.059 & 0.760 & 0.077 \\
\hline F statistic & 142.187 & & 75.288 & & 93.485 & & 32.852 & \\
\hline Durbin-Watson & 2.014 & & 1.980 & & 1.576 & & 1.155 & \\
\hline Adjusted R-square & 0.615 & & 0.805 & & 0.695 & & 0.588 & \\
\hline Scenario 1.2 & Coefficient & Sig. & Coefficient & Sig. & Coefficient & Sig. & Coefficient & Sig. \\
\hline (constant) & 2.676 & 0.413 & 1.698 & 0.573 & 0.850 & 0.724 & 2.662 & 1.027 \\
\hline SOC & -0.008 & 0.009 & -0.045 & 0.016 & -0.006 & 0.012 & -0.031 & 0.021 \\
\hline CASH_TA & -2.286 & 0.640 & -2.206 & 0.957 & -1.893 & 0.869 & 3.567 & 1.405 \\
\hline LNTR & 0.743 & 0.039 & 0.774 & 0.076 & 0.894 & 0.060 & 0.758 & 0.076 \\
\hline F statistic & 140.443 & & 84.320 & & 88.317 & & 34.676 & \\
\hline Durbin-Watson & 2.002 & & 1.946 & & 1.562 & & 1.175 & \\
\hline Adjusted R-square & 0.612 & & 0.822 & & 0.682 & & 0.601 & \\
\hline Scenario 1.3 & Coefficient & Sig. & Coefficient & Sig. & Coefficient & Sig. & Coefficient & Sig. \\
\hline (constant) & 2.196 & 0.479 & 1.058 & 0.715 & -0.868 & 0.750 & 2.543 & 1.047 \\
\hline GOV & 0.016 & 0.014 & 0.026 & 0.020 & 0.054 & 0.017 & -0.047 & 0.039 \\
\hline CASH_TA & -2.413 & 0.647 & -3.086 & 1.040 & -2.011 & 0.830 & 3.599 & 1.424 \\
\hline LNTR & -0.745 & 0.039 & 0.911 & 0.065 & 0.967 & 0.061 & 0.757 & 0.076 \\
\hline F statistic & 140.903 & & 73.916 & & 99.398 & & 34.074 & \\
\hline Durbin-Watson & 2.030 & & 2.016 & & 1.698 & & 1.171 & \\
\hline Adjusted R-square & 0.613 & & 0.802 & & 0.708 & & 0.597 & \\
\hline
\end{tabular}


The regression analysis results for the first scenario indicate that a percentage between $58 \%$ and $81 \%$ of the total variation in the market value of the companies acting in energy industry, both globally and per region, may be explained by combined and specific ESG factors' disclosure, when controlling for revenues and cash scaled by total assets.

The results presented in Table 5 supports both a positive and a negative association between the combined and individual ESG factors disclosure and firm's value measured by market value. The findings are consistent with the main hypothesis developed in the research model, assuming that there is an association between ESG factors disclosure and the firm's value for international companies within Energy industry. Previous studies (Sadiq et al., 2020; Li et al., 2018; Fatemi et al., 2018; Yoon et al., 2018; Yu et al., 2018; Wong et al., 2020; Horváthová, 2010) found similar results in what concerns the relationship between ESG factors disclosure and firm's value.

Considering the significance of the influence, the impact of the independent variables (combined ESG factors and individual factors - ENV, SOC and GOV) on the market value become significant for the overall sample and for each region analysed. Disaggregating the statistic outputs on each region and scenario, it can be observed that for the overall sample, North America, and Europe regions, there is a positive and significant association between the combined ESG factors, individual factors (ENV and GOV) and firm's value represented by market value. A negative and significant connection has been developed between the individual social factor (SOC) and the value of the company. As for the influence of the control variables used in the research model, only total revenues (LNTR), for the overall sample only, have a significant influence on the dependent variable (positive for scenario 1, scenario 1.1 and scenario 1.2, and negative for scenario 1.3). For Asia region, the statistics outputs show a negative and significant connection between the combined and individual ESG factors' disclosure and the firm's value represented by natural logarithm of market value.

The association between ESG combined scores and firm's value represented by Tobin's Q on regions is assessed in the second main scenario (Scenario 2) presented in Table 6. The regression model is the following: Tobin's $Q_{t}=\beta_{0}+$ $\beta_{1} E S G_{t}+\beta_{2} C A S H_{-} T A_{t}+\beta_{3} L N T R_{t}+\varepsilon t$. Three sub-scenarios are disaggregated from Scenario 2, to evaluate the correlation between each of the ESG factor (environment, social and corporate governance) and firm's value, represented in this scenario by Tobin's Q. The regions selected are North America, Europe and Asia based on the outputs resulted from SPSS software.

For the second research model applied to the data set, only a percentage between $1 \%$ and $40 \%$ of the total variation in firm's value (dependent variable - Tobin's Q) for companies acting in energy industry may be explained by the combined and 
individual ESG factors' disclosure (considered as independent variable, ESG combined score - scenario 2, environment score - scenario 2.1, social score scenario 2.2 and corporate governance score - scenario 2.3 ), explaining on a very limited degree the total variation in firm's value for the overall sample and the three main regions analysed (Asia, Europe and North America).

Table 6. The impact of Tobin's Q on ESG factors' disclosure

\begin{tabular}{|c|c|c|c|c|c|c|c|c|}
\hline $\begin{array}{l}\text { Dependent } \\
\text { Variable: }\end{array}$ & Overall s & iple & North A & rica & Euro & & Asi: & \\
\hline Scenario 2 & Coefficient & Sig. & Coefficient & Sig. & Coefficient & Sig. & Coefficient & Sig. \\
\hline (constant) & 1.040 & 0.219 & 0.311 & 0.551 & 0.553 & 0.363 & 1.780 & 0.396 \\
\hline ESG & 0.001 & 0.002 & 0.011 & 0.005 & 0.000 & 0.002 & -0.002 & 0.004 \\
\hline CASH_TA & 1.157 & 0.301 & 0.380 & 0.802 & 1.284 & 0.401 & 2.205 & 0.537 \\
\hline LNTR & -0.057 & 0.018 & -0.026 & 0.053 & -0.010 & 0.028 & -0.114 & 0.028 \\
\hline F statistic & 9.949 & & 1.449 & & 3.915 & & 16.016 & \\
\hline Durbin-Watson & 2.103 & & 2.281 & & 2.062 & & 2.116 & \\
\hline $\begin{array}{l}\text { Adjusted R- } \\
\text { square }\end{array}$ & 0.092 & & 0.024 & & 0.067 & & 0.402 & \\
\hline Scenario 2.1 & Coefficient & Sig. & Coefficient & Sig. & Coefficient & Sig. & Coefficient & Sig. \\
\hline (constant) & 1.031 & 0.225 & 0.197 & 0.672 & 0.640 & 0.340 & 1.460 & 0.408 \\
\hline ENV & 0.002 & 0.005 & 0.020 & 0.014 & -0.003 & 0.006 & 0.007 & 0.010 \\
\hline CASH_TA & 1.160 & 0.301 & 0.503 & 0.826 & 1.270 & 0.401 & 1.985 & 0.562 \\
\hline LNTR & -0.056 & 0.018 & 0.010 & 0.055 & -0.013 & 0.028 & -0.111 & 0.028 \\
\hline F statistic & 9.960 & & 0.738 & & 4.011 & & 16.035 & \\
\hline Durbin-Watson & 2.104 & & 2.346 & & 2.070 & & 2.161 & \\
\hline $\begin{array}{l}\text { Adjusted R- } \\
\text { square }\end{array}$ & 0.092 & & -0.015 & & 0.069 & & 0.402 & \\
\hline Scenario 2.2 & Coefficient & Sig. & Coefficient & Sig. & Coefficient & Sig. & Coefficient & Sig. \\
\hline (constant) & 1.092 & 0.194 & 0.901 & 0.497 & 0.560 & 0.336 & 1.932 & 0.381 \\
\hline SOC & 0.000 & 0.004 & 0.021 & 0.014 & -0.001 & 0.006 & -0.011 & 0.008 \\
\hline CASH_TA & 1.165 & 0.301 & 0.560 & 0.830 & 1.280 & 0.403 & 2.229 & 0.521 \\
\hline LNTR & -0.057 & 0.018 & -0.069 & 0.066 & -0.010 & 0.028 & -0.114 & 0.028 \\
\hline F statistic & 9.892 & & 0.808 & & 3.918 & & 16.933 & \\
\hline Durbin-Watson & 2.101 & & 2.304 & & 2.061 & & 2.079 & \\
\hline $\begin{array}{l}\text { Adjusted R- } \\
\text { square }\end{array}$ & 0.091 & & -0.011 & & 0.067 & & 0.416 & \\
\hline Scenario 2.3 & Coefficient & Sig. & Coefficient & Sig. & Coefficient & Sig. & Coefficient & Sig. \\
\hline (constant) & 0.976 & 0.225 & 0.003 & 0.559 & 0.391 & 0.362 & 1.864 & 0.389 \\
\hline GOV & 0.005 & 0.006 & 0.044 & 0.016 & 0.005 & 0.008 & -0.015 & 0.015 \\
\hline CASH_TA & 1.125 & 0.304 & -0.333 & 0.813 & 1.269 & 0.400 & 2.229 & 0.529 \\
\hline LNTR & -0.054 & 0.018 & 0.006 & 0.051 & -0.003 & 0.029 & -0.114 & 0.028 \\
\hline F statistic & 10.152 & & 2.639 & & 4.070 & & 16.405 & \\
\hline Durbin-Watson & 2.104 & & 2.175 & & 2.061 & & 2.097 & \\
\hline $\begin{array}{l}\text { Adjusted R- } \\
\text { square }\end{array}$ & 0.094 & & 0.083 & & 0.070 & & 0.408 & \\
\hline
\end{tabular}

The results presented in Table 6 show a similar impact of ESG factors' disclosure on the firm's value, when using Tobin's as the dependent variable as compared to the market value of the company. Even though it may seem that the combined and individual ESG factors may have a significant impact on firm's value $(\mathrm{p}<0.05)$, Adjusted R-square should be considered when performing this assessment (with a maximum significance level of 95\%). Advancing the analysis on regions and secondary scenarios, for the overall sample and North America, there is a positive and significant association between the combined and individual ESG factors and the value of the company. Regarding Europe region, the outputs obtained show 
both a positive (scenario $2-\mathrm{ESG}$ as independent variable; scenario $2.3-\mathrm{GOV}$ as independent variable) and negative (scenario 2.1 - ENV and scenario $2.2-\mathrm{SOC}$ ) significant connection between the combined and individual ESG factor's disclosure and firm's value.

The Asia region has registered the highest value of Adjusted R-square (approximatively 40\%), nonetheless, a limited variation of the dependent variable (Tobin's Q) is explained though the independent variables (ESG factors). The results obtained for Asia present a negative and significant association between the combined ESG factors, social factor (SOC - scenario 2.2) and corporate governance (GOV - scenario 2.3) and Tobin's Q representing the value of the company. In what concerns the relation between the environmental pillar and firm's value, a positive and significant relation was obtained for companies from Asia. The lack of significance resulted for the second linear regression model related to the main and the three sub-scenarios makes impossible for the hypotheses to be validated.

The impact of the control variable LNTR on the dependent variable, Tobin's Q is negative and significant for the overall sample, for companies from Asia and Europe when considering both combined and individual ESG scores. As for the trend, an increase of the firm's value measured by Tobin's Q, may be associated with an increase in cash ratio, but with a decrease in total revenues, both globally and regionally.

\section{Discussion and conclusion}

This research investigates the associations between ESG factors disclosure and firm's value for companies acting in energy sector. Previous empirical evidence supports mixed results when unidirectional linear relationships are tested. Based on the findings of this research, particular discussion is conducted for three geographical regions. Thus, the results support the hypothesis that there is an association between ESG factors disclosure and firm's value for companies from energy industry. The results are similar with other studies (Sadiq et al., 2020; Li et al., 2018; Fatemi et al., 2018; Horváthová, 2010) investigating this relationship.

The regression models were designed for the combined ESG factors and then extended by replicating them for each factor (environment, social and corporate governance). Findings confirm that both the individual (environment - ENV, social - SOC, and corporate governance) and the combined ESG factors are significantly connected with the value of the company measured in the first regression model by market value and in the second model by Tobin's $Q$.

Displaying the results obtained for each research model, scenario, and region it can be noticed that for the first regression model (market value used as the dependent 
value), both a positive and negative significant connection has been obtained between ESG factors disclosure and firm's value. Consequently, there is a positive and significant association between the combined ESG factors, individual factors (ENV and GOV) and firm's value for the overall sample, North America, and Europe regions. A negative association has been identified between the social factor (SOC) and firm's value, for the overall sample and the three regions analyzed (North America, Europe, and Asia). Concluding on the outputs obtained for Asia region, a negative and significant association exists between individual and combined ESG factors disclosure and market value.

The second research model applied reveals that a limited percentage of the total variation in firm's value for companies acting in energy industry, both globally and per region, may be explained by combined and specific ESG factors' disclosure, when controlling for revenues and cash scaled by total assets. The low levels of Adjusted R-square make impossible the validation of the main and secondary hypotheses for the second regression model. Nonetheless, for the overall sample and North America, a positive and significant association between the combined and individual ESG factors and the value of the company exists. The outputs obtained for Europe present both a positive (scenario 2 - ESG as independent variable; scenario 2.3 - GOV as independent variable) and a negative (scenario 2.1 - ENV and scenario 2.2 - SOC) significant connection between ESG factor's disclosure and the value of the company. Energy companies from Asia present a negative and significant association between the combined ESG factors, social factor (SOC - scenario 2.2) and corporate governance (GOV - scenario 2.3) and Tobin's Q representing the value of the company. A positive and significant correlation exists between the environmental pillar and firm's value.

The main contribution of this investigation to the literature consists of the evidence obtained about the association between ESG factors disclosure and firm's value by using two different dependent variables that have enhanced the certainty regarding the evidence obtained for the investigated association. The positive relationship may encourage executives to adopt an ESG disclosure policy in order to enhance the value of the company and thus, attract new investors and capital, but not limited to this. By presenting aspects related with the environment and human capital, the management of the company show its serious consideration and commitment to these aspects.

Future research may be extended into determining whether an association between ESG factors disclosure and firm's value exists for companies from other sensitive industries, but also for companies from non-sensitive industries. In addition, a comparison between companies from different regions may also discovered different attitudes towards the ESG factors disclosure and their impact on the value of the company. A difference in difference analysis may also be conducted on a generalized sample including companies from all industries. Particularities of the 
companies from sensitive industries as compared to companies from non-sensitive industries may be identified.

\section{Acknowledgements}

We appreciate the helpful comments and the constructive suggestions on previous drafts of this study presented at the International Conference Accounting and Management Information Systems (AMIS 2020), Bucharest, Romania. Special thanks are addressed to the anonymous reviewers of this research for their insightful recommendations.

\section{References}

Anning, F. (2018) „An assessment of the traditional theory of firm based assumption of profit maximization in an organization", SSRN Electronic Journal, DOI: 10.2139/ssrn.3235066

Alareeni, B.A. \& Hamdan, A. (2020) „ESG impact on performance of US S\&P 500 - listed companies", Corporate Governance, 20(7): 1409-1428

Brammer, S., Brooks, C., \& Pavelin, S. (2006) „Corporate social performance and stock returns: UK evidence from disaggregate measures", Financial Management, 35: 97-116

De Lucia, C., Pazienza, P., \& Bartlett, M. (2020) „Does good ESG lead to better financial performances by firms? Machine learning and logistic regression models of public enterprises in Europe", Sustainability, 2020(12): 1-26

Fatemi, A., Glaum, M. \& Kaiser, S. (2018) „ESG performance and firm value: The moderating role of disclosure", Global Finance Journal, 38: 45-64

Friede, G., Busch, T. \& Bassen, A. (2015) „ESG and financial performance: aggregated evidence from more than 2000 empirical studies", Journal of Sustainable Finance \& Investment, 5(4): 210-233

Horváthová, E. (2010) „Does environmental performance affect financial performance? A meta-analysis", Ecological Economics, 70: 52-59

Hughey, C.J., \& Sulkowski, A.J. (2012) „More disclosure better CSR reputation? An examination of CSR reputation leaders and laggards in the global oil \& gas industry", Journal of Academic Business Economy, 12: 24-34

Li, Y., Gong, M., Zhang, X-Y., \& Koh, L. (2018) „The impact of environmental, social, and governance disclosure on firm value: The role of CEO power", The British Accounting Review, 50: 60-75

Liu, Z. (2020) „Unravelling the complex relationship between environmental and financial performance - A multilevel longitudinal analysis", International Journal of Production Economics, 219: 328-340 
Lu, W., Chau, K.W., Wang, H., \& Pan, W. (2014) „A decade's debate on the nexus between corporate social and corporate financial performance: a critical review of empirical studies 2002-2011", Journal of Cleaner Production, 79: 195-206

Lungu, C.I, Caraiani, C., Dascalu, C. (2019) „Multidisciplinary approach of sustainable performance - financial performance nexus. The perspective of energy industry corporations", Proceedings of the 14th international conference accounting and management information systems (AMIS IAAER 2019), pp. 365-387

Patari, S., Arminen, H., Tuppura, A., \& Jantunen, A. (2014) „Competitive and responsible? The relationship between corporate social and financial performance in the energy sector", Renewable and Sustainable Energy Reviews, 37: 142-154

Richardson, A. J., \& Welker, M. (2001) „Social disclosure, financial disclosure and the cost of equity capital", Accounting, Organizations and Society, 26(7): 597-616

Sadiq, M., Singh, J., Raza, M., \& Mohamad, S. (2020) „The impact of Environmental, Social and Governance Index on firm value: Evidence from Malaysia", International Journal of Energy Economics and Policy, 10(5): 555-562

Setyahuni, S. W. \& Handayani, R., S. (2020) „On the value relevance of information on environmental, social, and governance (ESG): An evidence from Indonesia", Journal of Critical Reviews, 7(12): 50-58

Soytas, M.A., Denizel, M., \& Usar, D. (2017) „Corporate sustainability: Empirical evidence of causality on financial performance", Working Paper

Thomson Reuters (2017) „Methodology 2017 Thomson Reuters Top 100 Global Energy Leaders", available online at https://www.thomsonreuters.com /en/products-services/energy/top-100/methodology.html, ( $3^{\text {rd }}$ of May 2020)

Thomson Reuters (2017) „Top 100 Global Energy Leaders”, available online at https://www.thomsonreuters.com/en/products-services/energy/top-100.html, ( $3^{\text {rd }}$ of May 2020)

Wong, W.C., Batten, J. A., Ahmad, A. H., Mohamed-Arshad, S. M., Nordin, S., \& Adzis, A. A. (2020) „Does ESG certification add firm value?”, Finance Research Letters, https://doi.org/10.1016/j.frl.2020.101593

Yoon, B., Hwan Lee, J. \& Byun, R. (2018) „Does ESG performance enhance firm value? Evidence from Korea", Sustainability, 10: 1-18.

Yu, E.P., Guo, C. Q., \& Luu, B.V. (2018) „Environmental, social and governance transparency and firm value", Wiley Business Strategy and the Environment, 27(7): 987-1004

Zhao, C., Guo, Y., Yuan, J., Wu, M., Li, D., Zhou, Y. \& Kang, J. (2018) „ESG and corporate financial performance: Empirical evidence from China's listed power generation companies", Sustainability, 10: 1-18 